[Vicino Oriente XVII (2013), pp. 115-133]

\title{
A GROUP OF METAL WEAPONS FROM TELL EL-'AJJUL IN THE HUNTERIAN MUSEUM, UNIVERSITY OF GLASGOW
}

\author{
Angela Massafra - Sapienza University of Rome
}

Il contributo prende spunto dall'identificazione di un piccolo lotto di armi in metallo conservate nei magazzini dell'Hunterian Museum presso l'Università di Glasgow. I materiali, studiati a partire dai documenti originari conservati presso lo stesso istituto, sono stati in seguito analizzati tipologicamente, identificandone al contempo i contesti di rinvenimento per una più puntuale categorizzazione tipologica e funzionale. Lo studio delle armi vuole essere punto di partenza per più ampie considerazioni sulla Palestina meridionale tra la fine del III e la metà del II millennio a.C.

Keywords: Hunterian Museum; Tell el-‘Ajjul; weapons; metals; $3^{\text {rd }}-2^{\text {nd }}$ millennium BC

\section{INTRODUCTION: THE HUNTERIAN MUSEUM AT THE UNIVERSITY OF GLASGOW ${ }^{1}$}

Among the rich collection of antiquities in the "Egypt and Near East Collection" at the Hunterian Museum of the University of Glasgow, a group of bronze weapons from the site of Tell el-'Ajjul shows a particular interest, for being only partially published in the preliminary report and for having been often omitted, for the mentioned reason, from the following literature on the topic.

The Hunterian, Scotland's oldest museum, opened in 1807, was named after William Hunter, former student at the University of Glasgow, then obstetrician and teacher, but above all collector, in the era of most extensive European tradition of collecting and acquisitiveness. ${ }^{2}$ Before his death, Hunter arranged a trustee to place within the University of Glasgow his vast collection, ${ }^{3}$ that is now divided into a "Museum" and an "Art Gallery", both hosting, beside the permanent displays, several events and exhibitions. ${ }^{4}$ Though the major part of the archaeological material from the Levant held in the museum comes from Jericho, as gifts from J. Garstang and K.M. Kenyon, a smaller section of it has been received by the British School of Archaeology in Egypt from its excavations at Tell el'Ajjul.

Dealing with the material from the site of Tell el-'Ajjul can be quite puzzling, mainly because of the lack of a comprehensive publication. To pursue this aim, a long lasting project is currently carried on by R.T. Sparks (and previously also by P.J. Ucko) of the Institute of Archaeology, University College London, where the major part of the material from Tell el-'Ajjul is kept. The Institute is accomplishing a complete publication through

1 I wish to thank the Hunterian Museum, University of Glasgow, for its permission to access and study the material presented in this contribution. In particular, my gratitude goes to Prof. David Gaimster, Director of the Museum, Malcolm Chapman, Head of Collections Management, Dr. Sally-Anne Coupar, Curator of Archaeology and to Jayne Stewart of the Collections Management Department.

2 Keppie 2007, 18.

3 Arda - Knapp - Webb 2005, 7; Keppie 2007, 32, 115, 122-129.

4 http://www.gla.ac.uk/hunterian/. 
the Internet of only item in the vast collection..$^{5}$ Minor amounts of material from the site are kept in several different collections of the UK, ${ }^{6}$ among which a small but interesting lot (about 60 items) is kept at the Hunterian Museum, Glasgow.

\section{THE MATERIAL}

The material held at the Hunterian Museum here studied comprises 8 metal weapons from Tell el-'Ajjul: an adze, four daggers and three arrowheads. Among them, only the four daggers are showed in the original reports, with an outline drawing, while neither the adze nor the arrowheads have ever been published. Two of the daggers (cat. nos. 2-3) have been acquired by the Hunterian Museum in $1932,{ }^{7}$ while the remaining part has been delivered in 1938 by the British School of Archaeology in Egypt. ${ }^{8}$

The adze cat. no. 1 (fig. 1) belongs to a simple type: it has a plain blade with a widening cutting edge and a rectangular cross-section. The cutting edge is of a plano-convex kind, determining its interpretation as an adze rather than an axe..$^{9}$ It is preserved for a length of $6.2 \mathrm{~cm}$, though the blade is broken before the butt, so there is no information regarding its connection to the handle. It is $0.6 \mathrm{~cm}$ thick, making it possible to classify it as belonging to the "thin adze" group ${ }^{10}$ while the width is $3.7 \mathrm{~cm}$. The blade sides are straight but gradually widening towards the cut, where extensive hammering created an expanded edge, making it likely to be ascribed to Miron's type II-I d. ${ }^{11}$ A good comparison can be found within the same site of Tell el-'Ajjul. ${ }^{12}$ The typology of the simple blade, especially of some kinds, as it is the case of Miron's Type $\mathrm{II}_{-}$, has a long lasting life, starting from the Chalcolithic and continuing through the $2^{\text {nd }}$ millennium $\mathrm{BC}:{ }^{13}$ anyway, a date within the $\mathrm{EB} \mathrm{IV}^{14}$ can be supposed for our specimen from its context $(\S 3$.).

5 http://www.ucl.ac.uk/archaeology/research/directory/petrie sparks; Ucko 1998, 351-399; Sparks 2002, 48; 2005, 23. The collection is accessible at: http://archcat.museums.ucl.ac.uk/.

6 The British Museum, London; Ancient Egyptian, Sudanese and Near Eastern Collection, Museum of Manchester; Ancient Egyptian Collection, Cyfarthfa Castle Museum And Art Gallery; Ancient Egyptian Collection, New Walk Leicester; Ancient Egyptian and Near Eastern Collection, Wilton Park; Ancient Egyptian and Near Eastern Collection, Barras Bridge Newcastle upon Tyne; Ancient Egyptian, Sudanese and Near Eastern Collection, Le Mans Crescent; Ancient Egyptian, Sudanese and Near Eastern Collection, Chambers Street Edinburgh; Ancient Egyptian, Sudanese and Near Eastern Collection, Kelvingrove Art Gallery \& Museum, Glasgow.

7 Records preserved at the University of Glasgow Library, Special Collections, MR 54/55. The two daggers are listed as part of the material sent by J. Garstang together with finds from Tell es-Sultan/Jericho on July 1st, 1932 , although the covering letter doesn't cite any antiquity from "ancient Gaza".

8 Records preserved at the University of Glasgow Library, Special Collections, MR 54/20-20a, signed by May L.M. Bonar, secretary of the British School of Archaeology in Egypt, on January 22nd, 1938.

9 Petrie 1907, 5; Miron 1992, 22.

10 Miron 1992, 5.

11 Miron 1992, 7.

12 Petrie 1934, 10, pl. XXV:256.

13 Miron 1992, 25

14 Probably attributable to EB IVB since much of the EB IV material from Tell el-'Ajjul is to be ascribed to the later part of the period (Dever 1980, 48) 
Dagger cat. no. $2^{15}$ (fig. 2) is made in arsenical copper, with a blade $26.7 \mathrm{~cm}$ long and $3.4 \mathrm{~cm}$ wide (at its widest point). It has a tapering shape with a marked midrib, determining a concave lozenge section. The blade is highly corroded, especially on the one side and near the tang. It has a concave-sided butt, with still discernible holes for securing a handle: parts of a row of three of them are more clearly visible on the one side of the tang. ${ }^{16}$ It can be ascribed to Type 4 of Philip's classification, ${ }^{17}$ distinguished by its considerable length, a trapezoidal side butt with three pair of rivets and the pronounced midrib. ${ }^{18}$ It is a type peculiar of the late EB IV southern Palestine, enlightening the high degree of regionalism of this period in the metallurgical industry, as confirmed by the chemical composition ( $\S$ 4.). Comparisons from the same site can be found within the cemetery 1500 , especially from tomb $1565,{ }^{19}$ while from other sites parallels have been documented from Tell edDuweir, ancient Lachish, ${ }^{20}$ all to be ascribed to the EB IV period.

Dagger cat. no. $3^{21}$ (fig. 3), also made in copper, belongs to a different typology. It has a straight tapering blade, $28 \mathrm{~cm}$ long, sharpened on both sides with a flat lozenge-shaped cross section. The point is smoothed but, beside this, the blade shows an excellent preservation. The butt is formed by a tapered rib of a trapezoidal shape with six holes in two rows. One of the rivets which secured the blade with the handle is still preserved and inserted in one of the holes: its height, $3 \mathrm{~cm}$, can give us a hint about the width of the handle. The dagger belongs to Maxwell-Hyslop's Type $18,{ }^{22}$ to Kenyon's Type $\mathrm{II}^{23}$ and to Philip's Type 7;24 it is also dated to the EB IV. Several comparisons for it have been found in the necropolis of Tell es-Sultan/Jericho ${ }^{25}$ and in Beth Shean, ${ }^{26}$ while within the same site of Tell el-'Ajjul, it can be compared to some daggers from cemetery 1500, e.g. from tomb $1516 .{ }^{27}$ The date, within the EB IV, is probably around $2300-2150 \mathrm{BC}$, especially in the light of the comparison from Jericho. ${ }^{28}$ This shape is also confined, like the previous one, to the southern part of Palestine, with the major part of specimens found in Tell el-'Ajjul itself. $^{29}$

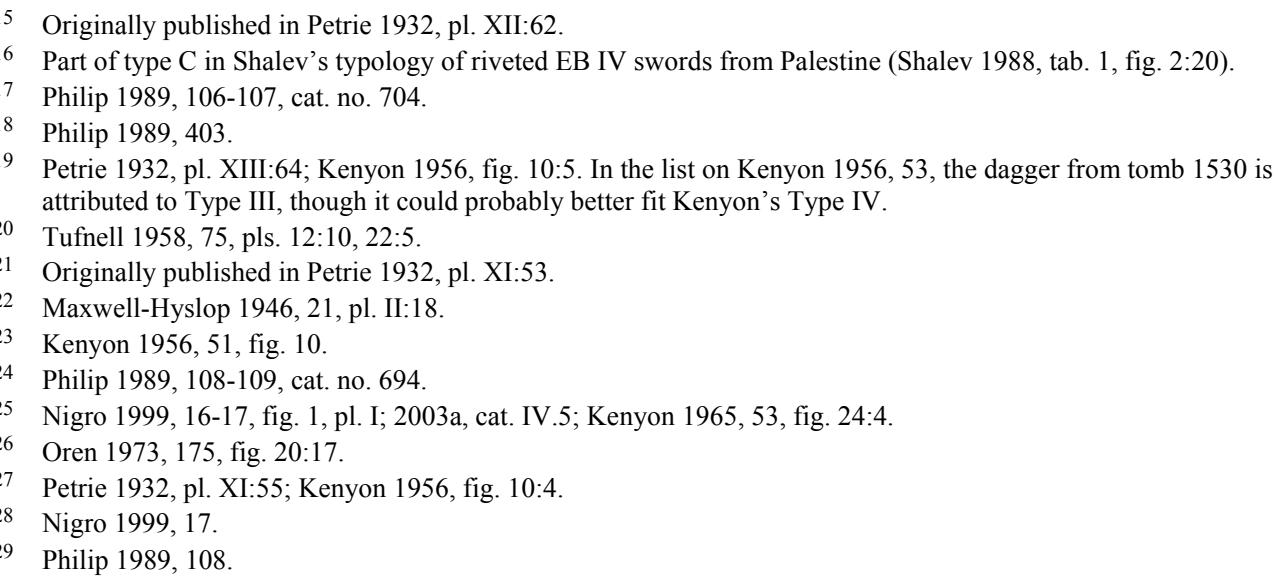


Dagger cat. no. $4^{30}$ (fig. 4) is bronze made. Its good state of preservation permits to appreciate its roughly triangular shape with a long and narrow tang, for a total length of $21.2 \mathrm{~cm}$ and a width of $4.1 \mathrm{~cm}$. The blade is flat, with a double convex cross section. The peculiarity of this type is the rounded point, too widespread in the typology to be explained as a result of wear, but to be interpreted as a deliberate feature, meaning that these weapons were not intended for stabbing: the attention paid to the sharpness of the blade edges suggests their use as a cutting tool. This peculiarity allows the weapon to be ascribed to Philip's Type $10 . .^{31}$ This kind of dagger is part of a typologically long lasting tradition, originated in the $18^{\text {th }}$ century Southern Levant and living until the early Iron Age: ${ }^{32}$ other specimens have been found in Tell el-Jazari, ancient Gezer, ${ }^{33}$ Tell es-Sultan/Jericho, ${ }^{34}$ Tell el-Mutesellim/Megiddo, ${ }^{35}$ Tell el-Far'ah (South), ${ }^{36}$ Tell ed-Duweir. ${ }^{37}$ Nevertheless, the broader and shorter blade and shorter tang in comparison to the similar specimens of the LB and the absence of rivets to secure the tang allows to assign it stylistically to the MB IIIII, the age of the major flourishing of the type. ${ }^{38}$ Their major area of distribution of the type is central and southern Palestine. ${ }^{39}$

The fourth dagger of the collection, cat. no. $5^{40}$ (fig. 5) is bronze made, $21 \mathrm{~cm}$ long, 3.9 $\mathrm{cm}$ wide. It has a long and broad blade, with a flat midrib ending in a sharpened point, meaning its use as a stabbing weapon. ${ }^{41}$ It is characterized by a short tang without rivet holes. The shorter tang and the shallow midrib make it likely to be compared to MaxwellHyslop's Type $26^{42}$ and to Philip's Type $17 .{ }^{43}$ It finds good parallels with specimens from Jericho, ${ }^{44}$ Gezer, ${ }^{45}$ Tell Beit Mirsim stratum $D^{46}$ and Tell el-Dab ${ }^{6} a{ }^{47}$ The type is confined to central-southern Palestine and to the Delta region, and it's dated to the MB II-III (1800$1600 \mathrm{BC})$.

The last items are three arrowheads: they are all made of bronze but belong to slightly different types. Cat no. 6 (fig. 6) was bent at the middle of the blade. Nevertheless, it is

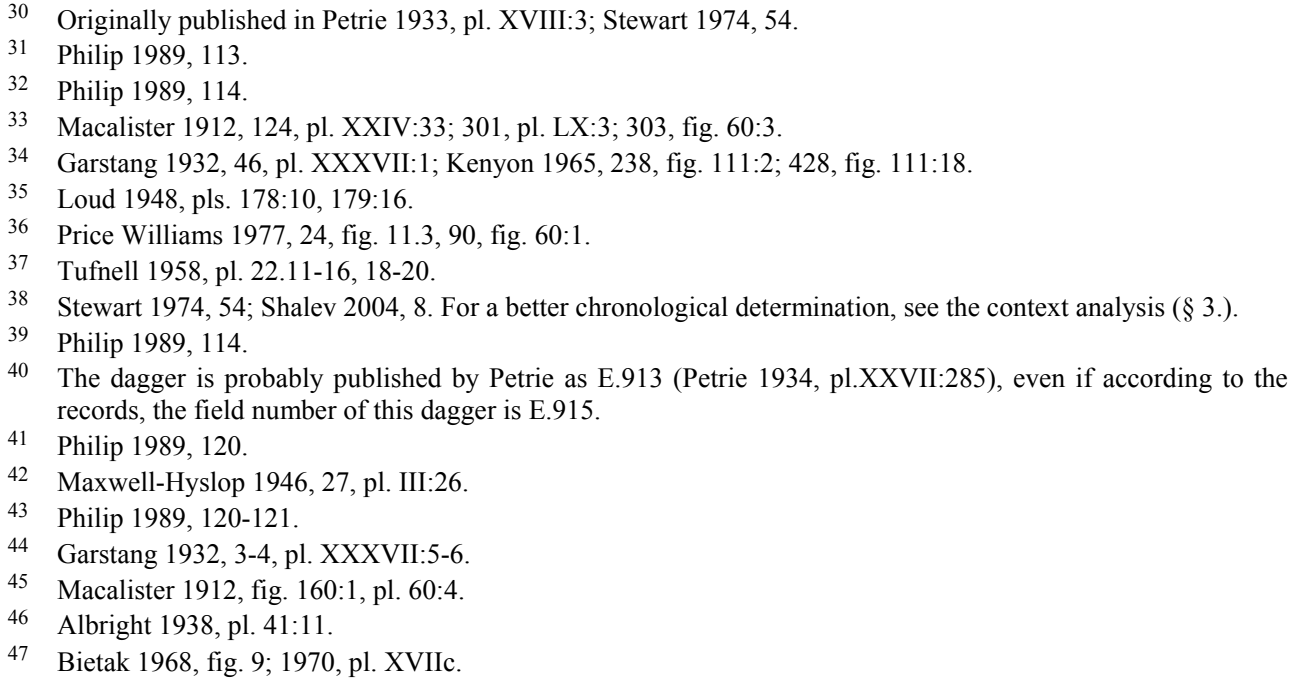


possible to suppose its original elliptic shape, with a flat blade, undistinguished stem and long tang with quadrangular cross section. It's the shortest one among our specimen, being only $6.5 \mathrm{~cm}$ long. Cat. no. 7 (fig. 7) has an oblong shape, $8 \mathrm{~cm}$ long, with a flat blade. It shows an undistinguished stem and a short tang with a quadrangular cross section. Slightly different form the previous ones, arrowhead cat. no. 8 has an oblanceolate shape with a central rib and flattened edges, an undistinguished stem and an elongated tang with a rhomboidal cross section. It's $11.5 \mathrm{~cm}$ long. The formal characteristics of the three specimens allow to assign them to different periods: particularly significant is the absence of a definite stem, that does not exist before the late LB, giving us a terminus ante quem for all the three specimens. A diagnostic element is also the tang section, squared in the late MB or early LB I, ${ }^{48}$ making nos. 6 and 7 likely to be dated within this period. On the other hand, a later date, within the LB I-II, is to be assumed for no. 8 (fig. 8), since it shows a rhomboidal section, that develops from the LB I, and a high midrib, also characteristic of the $\mathrm{LB}^{49}$

\section{THE CONTEXTS}

Dealing with Tell el-'Ajjul findings is not always an easy matter: some of them have not been published in the preliminary reports ${ }^{50}$ and a complete recording of all the material has been done only with regards to the Middle Bronze age by J.R. Stewart, who anyway didn't give too much importance to the contexts. ${ }^{51}$

Reports of the excavations by Petrie are characterized by the use of letters to define the region and the locus of the finding, while the single item is characterized by a number. When the item is named only with a number up to 550 or over 1200 , it means it has been recovered from a tomb. ${ }^{52}$ Bearing these aspects of Petrie's methodology in mind, it's easier to find out the original context of each finding.

Adze cat. no. 1, daggers nos. 2-3 and arrowheads cat. nos. 7-8 are all designed by a number (inferior to 550 in case of the adze, superior to 1200 for the remaining items).

The adze was originally named 178/81, determining its belonging to Cemetery 100-200. This necropolis is characterized by a different treatment of the bodies and different findings in respect to cemetery 1500 . Unfortunately, the former has been less documented by Petrie, maybe because of the presence in several tombs of scattered bones. In cemetery 100-200 the tombs were mainly formed by rounded shafts, dispersed or disarticulated bones and a major variety of pottery than cemetery 1500 . As for the weapons, daggers seem to be confined to cemetery 1500, while cemetery 100-200 bears a major amount of javelins, though no adze or axe seems to have been found. ${ }^{53}$ The first number of the mark has to be related to the tomb in which the item was found. No tomb with this name, though, appears

48 Cross - Milik 1956, 18; Tubb 1977, 193

49 Cross - Milik 1956, 18; Tubb 1977, 191

50 E.g. the correspondence between plans and lists of burials have been checked by Gonen, who found out they correspond only in about $75 \%$ of the cases (Gonen 1992, 70).

51 Stewart 1974

52 Petrie 1934, 2

53 Kenyon 1956, 46-47. 
in the excavation reports: group numbers 1-550 are published in Ancient Gaza I, but some numbers are missing. As it is possible to observe from the plan, the closer cluster (numbers 172-177) is located south the Upper Tunnel, ${ }^{54}$ making it likely a similar location for number 178.

Dagger no. 2 is designed by the number 1530: the related tomb is an EB IV burial within cemetery 1500 . The tomb belongs to Kenyon's type L2, being a rectangular pit, lined in rubble and originally roofed in stone..$^{55}$ It is not clear whether there was a separated shaft to enter the tomb or not. The burial was only characterized by the weapon and a single jar with ledge handles. ${ }^{56}$

Dagger no. 3 belongs to tomb 1551, a simple rectangular pit (Kenyon's type H2). ${ }^{57}$ The burial was accompanied by a teapot with ledge handles, together with the weapon. ${ }^{58}$

In both cases we are dealing with single burials, crouched, with a funerary set only composed by a weapon and a pot, ${ }^{59}$ defining a male burial but, probably more specifically, a warrior burial, outlining the presence of an elite already in the EB IV Tell el-'Ajjul. ${ }^{60}$

Arrowheads nos. 7 and 8 were respectively marked by numbers $1929^{61}$ and $1816 . .^{62}$ Both these tombs belong to the Lower Cemetery and have been published in Ancient Gaza IV, but no metal artifact is recorded. ${ }^{63}$ No other data are given about Tomb 1929, that is only recorded on the plan of the cemetery and on the general list of tombs, but nothing else is specified. ${ }^{64}$ Tomb 1816 was not marked in the plant, but it was probably the central burial of Group $1800 .^{65}$ It is a cist tomb with a dromos ${ }^{66}$ (= Petrie's "structural tomb"): rectangular in shape, single lined with stone slabs of kurkar sandstone, place horizontally, three courses in elevation. The burial chamber was accessible by a stepped dromos. It was found in a very bad state of preservation and no signs of roof were detected, ${ }^{67}$ but it was probably gabled as the Governor's Tomb 419 from the same cemetery. ${ }^{68}$ As this last tomb, also burial

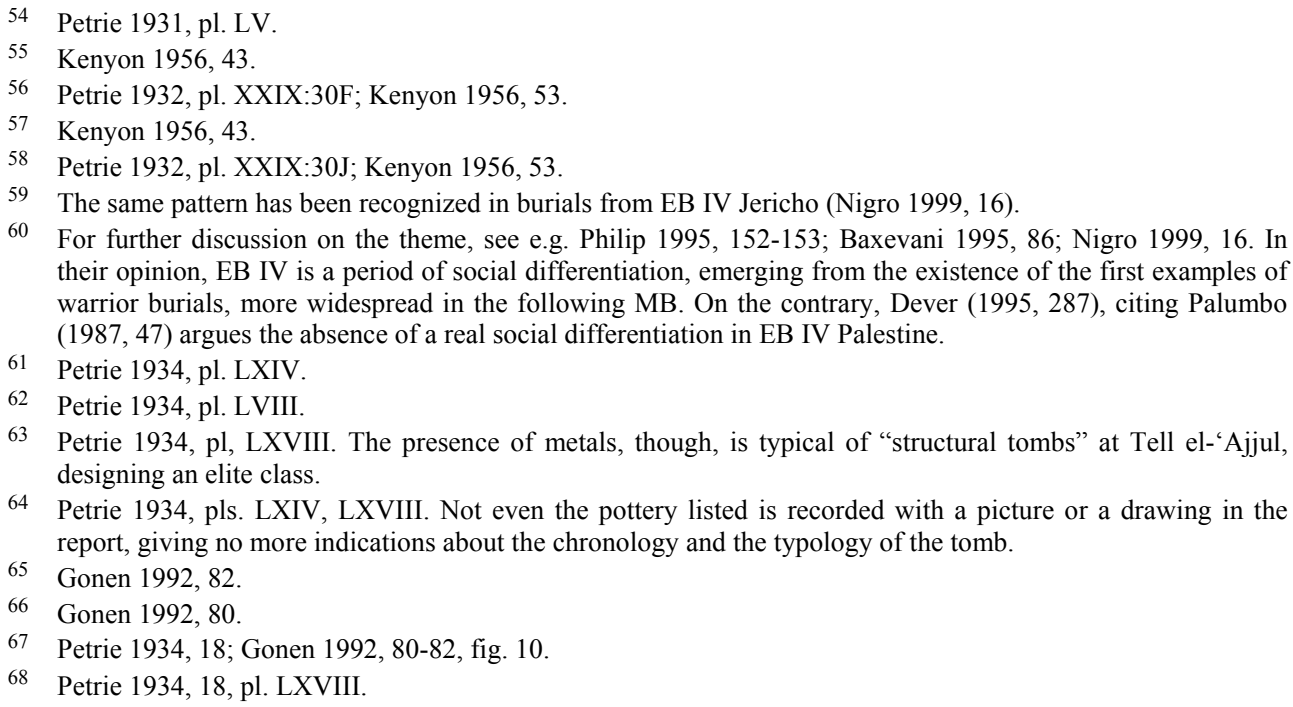


1816 was probably part of an elite group of the population, whose interments were distinguished by the presence of weapons. The tombs have been dated to the LB II. ${ }^{69}$

The other two daggers, nos. 4-5, and the remaining arrowhead, no. 6, are all characterized by one to three letters, the first designing the area/region and the others the locus, plus a number. They have all been found within the residential area at the southern edge of the city. Dagger no. 4 was marked by the acronym AN $720(=1020)$, meaning it was located in block A, locus N. This is the major road EW of the southern residential area, dividing block $\mathrm{A}$ in two parts, connected on its western part to block B. ${ }^{70}$ The area has been dated to the final part of $\mathrm{MB}$, between 1600 and $1550 \mathrm{BC}$, i.e. shortly before the destruction of the city by the army of Ahmose, though no destruction debris has been documented in this area. ${ }^{71}$ The road serves in particular a complex ("the civic complex"), that was probably a residence of officials, composed by some rooms, a bathroom, a shrine and several silos. ${ }^{72}$

Dagger no. 5 was originally named E 915. Region E has been excavated by Petrie in the years 1933-1934. ${ }^{73}$ It is located south-east of block A and it is part of the residential quarter too. ${ }^{74}$ The date is slightly earlier than block A, being attributed by finds to the transition between MB II and MB III (about $1650 \mathrm{BC}$ ). ${ }^{75}$

Finally, arrowhead no. 6 is marked as TDX 950. The name indicates one of the rooms of block $\mathrm{T}$, in the middle of the southern area of the mound. ${ }^{76}$ The complex is composed by a series of rooms of big dimensions, with a possible residential function ${ }^{77}$ and is dated to the same period as block E (1650 BC). ${ }^{78}$

\section{CHEMiCAL NOTES}

Chemical analyses have been executed only on the EB IV daggers, cat. nos. 2-3, showing a high percentage of arsenic in both of them (cat. no. 2: As 4.93; cat. no. 3: As 3.47; see catalogue for the full composition). ${ }^{79}$ This result, together with the other analyses of EB IV daggers from Tell el-'Ajjul, can give a precious hint for the understanding of the metallurgical techniques and their symbolic role in the period.

A total of 13 EB IV daggers from Tell el-'Ajjul have been analyzed through AAS methodology by P.R.S. Moorey - F. Schweirzer, ${ }^{80}$ L. Khalil, ${ }^{81}$ S. Shalev ${ }^{82}$ and G. Philip. ${ }^{83}$

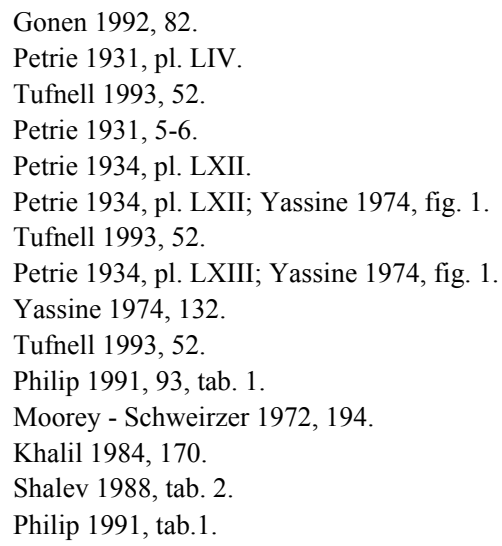


This corpus forms more than half of the total repertoire of 24 EB IV weapons from the site, including specimens representative of the different types. They are all made in arsenical copper, making it possible to exclude that the tin-bronze technology was in use at Tell el'Ajjul in this period. ${ }^{84}$

As it has been pointed out by Shalev, the "inverse segregation" property of copper arsenic alloys was exploited in such items, making it likely that this process was deliberately used by smiths in order to obtain a visual effect: for this property, when the core has a percentage of about $4.5-6 \%$ arsenic, the related percentage on the surface rises to approximately $28 \%$, creating a silvery surface, probably meant to imitate precious metals. ${ }^{85}$ If assuming the process was intentional, we must also admit it required specialized skills and a major effort, that was probably only reserved to a small amount of weapons, designed for an elite class of the population.

As for the metal supply, EB IV Tell el-'Ajjul probably exploited the ores from the Wadi Faynan. ${ }^{86}$ The high arsenic content was probably produced by co-smelting copper with an arsenic ore, or by the direct addition of an arsenic mineral to molten copper or by the mixing of another high-arsenic copper from other ores. ${ }^{87}$

\section{CONCLUSIONS}

From the previous considerations, it has been possible, beside widening the corpus of known material from the site, both to examine the function of metal weapons in the south Palestinian society of the end of the $3^{\text {rd }}$ and $2^{\text {nd }}$ millennia $\mathrm{BC}$ and to highlight the degree of regionalization of the area in the same period.

As for the first point, the social importance of metal weapons has been widely argued. ${ }^{88}$ It is worth noticing, though, how in Tell el-'Ajjul this character is visible already from the EB IV, when a real settlement is not yet known. Nevertheless, the presence of weapons in single crouched burials with a standardized funerary assemblage composed by a dagger and a pot (usually a jar or a teapot) highlights the presence of an elite, probably to be connected to the warrior burials phenomenon. ${ }^{89}$ Both the adze (cat. no. 1) and the daggers (cat. nos. 23 ) from the $3^{\text {rd }}$ millennium were probably produced as status symbols, as well shown by the intentional silvery surface made exploiting the "inverse segregation" property of arsenical copper alloy. A different aim has to be theorized for the MB daggers (cat. nos. 4-5) and for the arrowhead cat. no. 6, which have been found in the residential area: their date within the very end of the MB could be tentatively linked to the destructive events documented at the

84 Philip 1991, 93. This is true also of the typologically later examples, as the dagger with concave-sided butts and high midribs; the same typology in arsenical copper is also attested at Lachish (Tufnell 1958, 328), making it possible that it's typical of southern sites (probably because further from Syria, the bronze supplier or more probably because of a social factor, since the north was more linked to Syria). In the same era, tinbronze metallurgy was in use in northern sites, as Jericho (Philip 1991, 93).

85 Shalev 1988, tab. 2; Philip 1991, 97.

86 Large scale mining activities were carried on already in the EB II-III and continues in the EB IV (Adams 2000, 398; 2003, 18; Levy et al. 2002, 427).

87 Philip 1991, 100.

88 e.g. Philip 1989, 151; Nigro 2003a, 62-63; 2003b, 70-71.

89 Philip 1995, 152-153. 
middle of the $2^{\text {nd }}$ millennium in Tell el- Ajjul, connected to the expulsion of the "Hyksos" from Egypt and the following Palestinian campaigns led by Ahmose. These weapons were probably intended for their use in battle rather than for a purely ostentatious role. The remaining two arrowheads (cat. nos. 7-8) are emblems of the new tradition in funerary assemblages of the LB, when arrowheads became part of the mortuary kit, in contrast to the MB habit.

The assemblage is also a good proof of the strong regionalization of the end of the $3^{\text {rd }}$ and first half of the $2^{\text {nd }}$ millennium Southern Levant. This is particularly reflected by the daggers, the only item that can give us this kind of hint: all the four specimens fall within types peculiar to the central and southern part of Palestine. This phenomenon is also reflected by the chemical composition of the two EB IV daggers: the technology of arsenical copper is deliberately exploited in this period only in the southern part of the country, while the northern had already started using, probably borrowing the technology from Syria, the tin-bronze alloy practices. ${ }^{90}$

Concluding, the analysis of this assemblage of weapons from Tell el-'Ajjul permitted to shed some new lights on the site, wishing on a future complete comprehension of it, together with an inclusive publication of its material in its original context.

90 Philip 1991, 100. 


\section{Catalogue}

No. 1 - Adze (fig. 1)

Provenience: Tell el-'Ajjul

Excavation: W.F.M. Petrie, British School of Archaeology, Jerusalem

Field Number: 178/81

Collection: Egypt and Near East Collection,

Hunterian Museum, University of Glasgow,

Glasgow

Museum ID: D.1938.5

Material: copper

External colour: 5YR5/8 (red)

Width: $3.7 \mathrm{~cm}$ (at widest point)

Length: $6.2 \mathrm{~cm}$

Thickness: $0.6 \mathrm{~cm}$

Context: Tomb

Chronology: EB IVB (2200-2000 BC)

Publication: unpublished

No. 2 - Dagger (fig. 2)

Provenience: Tell el-'Ajjul

Excavation: British School of Archaeology, Jerusalem

Field number: 1530

Collection: Egypt and Near East Collection,

Hunterian Museum, University of Glasgow, Glasgow

Museum ID: D.1932.73

Material: arsenical copper

Chemical composition: $\mathrm{Cu} 95.2 ; \mathrm{Sn}<.10 ; \mathrm{Pb} 0.015$; $\mathrm{Zn}<.01$; As 4.93; Sb 0.23

External colour: 2.5 YR3/4 dark reddish brown

Width: $3.4 \mathrm{~cm}$ (at widest point)

Length: $26.7 \mathrm{~cm}$

Thickness: $0.4 \mathrm{~cm}$

Context: Tomb

Chronology: EB IVB (2200-2000 BC)

Publication: Ancient Gaza II, pl. XII:62

No. 3 - Dagger (fig. 3 )

Provenience: Tell el-'Ajjul

Excavation: British School of Archaeology, Jerusalem

Field number: 1551

Collection: Egypt and Near East Collection,

Hunterian Museum, University of Glasgow, Glasgow

Museum ID: D.1932.74

Material: arsenical copper

Chemical composition: $\mathrm{Cu} 94.8 ; \mathrm{Sn}<.12 ; \mathrm{Pb} 0.027$;

Zn 0.05; As 3.47; Sb 1.21.

External colour: 10YR5/8 (yellowish brown)

Width: $3.2 \mathrm{~cm}$ (at widest point)

Length: $28 \mathrm{~cm}$
Thickness: $0.4 \mathrm{~cm}$

Context: Tomb

Chronology: EB IV (2300-2150 BC)

Original publication: Ancient Gaza II, pl. XI:53

No. 4 - Dagger (fig. 4)

Provenience: Tell el-'Ajjul

Excavation: British School of Archaeology, Jerusalem

Field Number: AN $720=1020$

Collection: Egypt and Near East Collection, Hunterian Museum, University of Glasgow, Glasgow

Museum ID: D.1938.8/a

Material: bronze

External colour: 10Y-5GY4/2 (dark grayish green)

Width: $4.1 \mathrm{~cm}$ (at widest point)

Length: $21.2 \mathrm{~cm}$

Thickness: $0.5 \mathrm{~cm}$

Context: road, residential quarter

Chronology: MB III (1600-1550 BC)

Original publication: Ancient Gaza III, pl. XVIII:3.

No. 5 - Dagger (fig. 5)

Provenience: Tell el-'Ajjul

Excavation: British School of Archaeology, Jerusalem

Field Number: E 915

Collection: Egypt and Near East Collection,

Hunterian Museum, University of Glasgow, Glasgow

Museum ID: D.1938.8/b

Material: bronze

External colour: 7.5YR5/4 (brown)

Width: $3.9 \mathrm{~cm}$

Length: $21 \mathrm{~cm}$

Thickness: $0.3 \mathrm{~cm}$

Context: residential quarter

Chronology: MB III (1650 BC)

Original publication: Ancient Gaza IV, pl.XXVII:285

No. 6 - Arrowhead (fig. 6)

Provenience: Tell el-'Ajju

Excavation: British School of Archaeology, Jerusalem

Collection: Egypt and Near East Collection,

Hunterian Museum, University of Glasgow, Glasgow

Museum ID: D.1938.6/1

Field number: TDX.950

Material: bronze

Width: $1.5 \mathrm{~cm}$ (at widest point) 
Length: $6.5 \mathrm{~cm}$

Thickness:

Context: room, residential complex

Chronology: MB III (1650 BC)

Original publication: unpublished

No. 7 - Arrowhead (fig. 7)

Provenience: Tell el-'Ajju

Excavation: British School of Archaeology,

Jerusalem

Field number: 1929

Collection: Egypt and Near East Collection,

Hunterian Museum, University of Glasgow,

Glasgow

Museum ID: D.1938.6/3

Material: bronze

External colour: $10 \mathrm{Y}-5 \mathrm{GY} 5 / 2$ (grayish green)

Width: $1.4 \mathrm{~cm}$ (at widest point)

Length: $8 \mathrm{~cm}$

Thickness: $0.2 \mathrm{~cm}$ (head); $0.3 \mathrm{~cm}$ (tang)

Context: Tomb
Chronology: MB III -LB II (1500-1300 BC)

Original publication: unpublished

No. 8 - Arrowhead (fig. 8)

Provenience: Tell el-'Ajjul

Excavation: British School of Archaeology, Jerusalem

Field number: 1816

Collection: Egypt and Near East Collection, Hunterian Museum, University of Glasgow, Glasgow

Museum ID: D.1938.6/2

Material: bronze

Colour: $10 \mathrm{Y}-5 \mathrm{GY} 5 / 2$ (grayish green)

Width: $1.5 \mathrm{~cm}$ (at widest point)

Length: $11.5 \mathrm{~cm}$

Thickness: $0.3 \mathrm{~cm}$ (head); $0.4 \mathrm{~cm}$ (tang)

Context: Tomb

Chronology: LB II (1400-1200 BC)

Original publication: unpublished

\section{REFERENCES}

ADAMS, R.

2000 The Early Bronze age III-IV transition in southern Jordan: evidence from Khirbat Hamra Ifdan: G. PHILIP - D. BAIRD (eds.), Ceramics and Change in the Early Bronze Age of the Southern Levant (Levantine Archaeology 2), Sheffield 2000, pp. 379-401.

2003 External influences at Faynan during the Early Bronze age: a re-analysis of building I at Barqa el-Hetiye, Jordan: Palestine Exploration Quarterly 135 (2003), pp. 6-21.

ALBRIGHT, W.F.

1938 The Chronology of a South Palestinian City, Tell el-'Ajjul: American Journal of Semitic Languages and Literatures 55 (1938), pp. 337-359.

ARDA, B. - KNAPP, A.B. - WeBB, J.M.

2005 The collection of Cypriote antiquities in the Hunterian Museum University of Glasgow (Corpus of Cypriote antiquities 26), Sävedalen 2005.

BAXEVANI, E.

1995 The complex nomads: Death and Social stratification in EB IV Southern Levant: S. CAMPBELL - A. GREEN (eds.), The Archaeology of Death in the Ancient Near East (Oxbow Monograph 51), Oxford 1995, pp. 85-95.

BIETAK, $\mathrm{M}$.

1968 Vorläufiger Bericht über die erste und zweite Kampagne der österreichischen Ausgrabungen auf Tell ed-Daba im Ostdelta Ägyptens (1966/1967): Mitteilungen des Deutschen Archäologischen Instituts Abteilung Kairo 23 (1968), pp. 79-114.

1970 Vorläufiger Bericht über die dritte Kampagne der österreichischen Ausgrabungen auf Tell ed-Dab a: Mitteilungen des Deutschen Archäologischen Instituts Abteilung Kairo 26, pp. $15-41$.

Cross, F.M. - MiLik, J.T.

1956 A typological study of the el-Khadr javelin and arrow-heads: Annual of the Department of Antiquities of Jordan 3 (1956), pp. 15-23. 
DEVER, W.G.

1980 New vistas on the EB IV ('MB I') horizon in Syria-Palestine: Bulletin of the American Schools of Oriental Research 237 (1980), pp. 35-64.

1995 Social Structure in the Early Bronze IV period in Palestine: T.E. LEVY (ed.) The GARSTANG, J. Archaeology of Society in the Holy Land, London 1995, pp. 282-296.

1932 Jericho: City and Necropolis: Liverpool Annals of Anthropology and Archaeology XIX (1932), pp. 35-54.

GONEN, R.

1992 Burial patterns \& cultural diversity in Late Bronze age Canaan (ASOR Dissertation Series 7), Winona Lake 1992.

KENYON, K.M.

1956 Tombs of the Intermediate Early Bronze - Middle Bronze age at Tell Ajjul: Annual of the Department of Antiquities of Jordan 3 (1956), pp. 41-55.

1965 Excavations at Jericho, Vol. II. The Tombs excavated in 1955-8, London 1965.

KEPPIE, L.

2007 William Hunter and the Hunterian Museum in Glasgow, 1807-2007, Edinburgh 2007.

KHALIL, L.

1984 Metallurgical analyses of some weapons from Tell el-'Ajjul: Levant 16 (1984), pp. 167170 .

Levy, T.E. - Adams, R.B. - Hauptmann, A. - Prange, M. - Schmitt-Strecker, S. - NajJar, M.

2002 Early Bronze Age metallurgy: a newly discovered copper manufactory in southern LOUD, G.

1948 Megiddo II. Seasons 1935-39 (Oriental Institute Publication LXII), Chicago 1948.

MACALISTER, R.A.S.

1912 The excavation of Gezer: 1902-1905 and 1907-1909, London 1912.

MAXWELL-HYSLOP, R.

1946 Daggers and swords in Western Asia: Iraq 8 (1946), pp. 1-65.

MiRON, E.

$1992 \quad$ Axes and adzes from Canaan (Prähistorische Bronzefunde IX 19), Stuttgart 1992.

MOOREY, P.R.S. - SCHWEIZER, F.

1972 Copper and copper alloys in ancient Iraq, Syria and Palestine: some new analyses:

Nigro, L.

1996 Le residenze palestinesi del Bronzo Tardo. I modelli planimetrici e strutturali: Contributi e Materiali di Archeologia Orientale 6 (1996), pp. 1-69.

1999 Sei corredi tombali del Bronzo Antico IV dalla necropoli di Gerico ai Musei Vaticani: Monumenti Musei e Gallerie Pontificie XIX (1999), pp. 5-22.

2003a Dal rame al bronzo (senza trascurare l'oro e l'argento). La metallurgia e la nascita delle città-stato in Siria e Palestina nel III millennio a.C.: G. CAPRIOTTI ViTTOZZI (ed.), L’uomo, la pietra, i metalli. Tesori della terra dal Piceno al Mediterraneo, San Benedetto del Tronto 2003, pp. 62-69.

2003b Gioielli, armi, oggetti d'apparato, strumenti musicali: i metalli come status symbol nei contesti funerari e cultuali della Siria-Palestina nel II millennio a.C.: G. CAPRIOTTI Vittozzi (ed.) 2003, L’uomo, la pietra, i metalli. Tesori della terra dal Piceno al Mediterraneo, San Benedetto del Tronto 2003, pp. 70-75.

OREN, E.D.

1973 The northern cemetery of Beth Shan, Leiden 1973. 
Palumbo, G.

1987 The Early Bronze Age IV in the Southern Levant. Settlements Patterns, Economy, and Material Culture of a 'Dark Age': Bulletin of the American Schools of Oriental Research Petrie, W.M.F. 267 (1987), pp. 43-59.

1907 Tools and weapons, Warminster 1917.

1931 Ancient Gaza I. Tell el Ajjul (Publications of British School of Archaeology in Egypt, Egyptian Research Account 53), London 1931.

1932 Ancient Gaza II. Tell el Ajjul (Publications of British School of Archaeology in Egypt, Egyptian Research Account 54), London 1932.

1933 Ancient Gaza III. Tell el Ajjul (Publications of British School of Archaeology in Egypt, Egyptian Research Account 55), London 1933.

1934 Ancient Gaza IV. Tell el Ajjul (Publications of British School of Archaeology in Egypt, Egyptian Research Account 56), London 1934.

PHILIP, G.

1989 Metal weapons of the Early and Middle Bronze Ages in Syria-Palestine (British Archaeological Reports International Series 526), Oxford 1989.

1991 Tin, Arsenic, Lead: alloying practices in Syria-Palestine around 2000 BC: Levant 23, pp. 93-104.

1995 Warrior burials in the ancient Near-Eastern Bronze age: the evidence from Mesopotamia, Western Iran and Syria-Palestine: S. CAMPBELl - A. GREEN (eds.), The Archaeology of Death in the Ancient Near East (Oxbow Monograph 51), Oxford 1995, pp. 140-154.

PRICE-WiLliams, D.

1977 The Tombs of the Middle Bronze II Period from the "500" Cemetery at Tell el- Fara South, London 1977.

PRITCHARD, J.B.

$1955 \quad$ Ancient Near Eastern Texts relating to the Old Testament, Princeton 1955.

SETHE, K.

$1930 \quad$ Urkunden der Ägyptischen Altertums IV. Urkunden der 18. Dynastie, Leipzig 1930.

SHALEV, S.

1988 Redating the 'Philistine Sword' at the British Museum: a case study in typology and technology: Oxford Journal of Archaeology 7 (1988), pp. 303-311.

2004 Swords and Daggers in Late Bronze Age Canaan (Prähistorische Bronzefunde IV, 13),

SPARKS, R Stuttgart 2004.

2002 Strangers in a strange land: Egyptians in southern Palestine during the Bronze Age: Archaeology International 6 (2002), pp. 48-51, DOI: http://dx.doi.org/10.5334/ai.0614.

2005 The Lost Loci of Tell el-‘Ajjul: Petrie's Area C: Palestine Exploration Quarterly 137 (2005), pp. 23-29.

STEWART, J.R.

1974 Tell el-'Ajjul: the Middle Bronze age remains (Studies in Mediterranean Archaeology 38), Goteborg 1974.

TUBB, J.N.

1977 Three inscribed arrowheads from Tell el-'Ajjul: Bulletin of the Institute of Archaeology, University of London 14 (1977), pp. 191-195. 
TUFNELL, O.

$1958 \quad$ Lachish (Tell el Duweir) IV: The Bronze Age, Oxford 1958.

1993 'Ajjul, tell el-: E. STERN (ed.), The New Encyclopedia of Archaeological Excavations in the Holy Land, vol. I, Jerusalem 1993, pp. 49-52.

UCKO, P.J.

1998 The biography of a collection: The Sir Flinders Petrie Palestinian Collection and the role of University Museums: Museum Management and Curatorship 17 (1998), pp. 351-399.

VANDERSLEYEN, C.

1971 Les guerres d'Ahmosis, fondateur de la XVIIIe dynastie (Monographies Reine Elisabeth 1), Paris 1971.

YASSINE, K.N.

1974 City planning of Tell el-'Ajjul. Reconstructed Plan (Fig. 1): Annual of the Department of Antiquities of Jordan 19 (1974), pp. 129-133. 

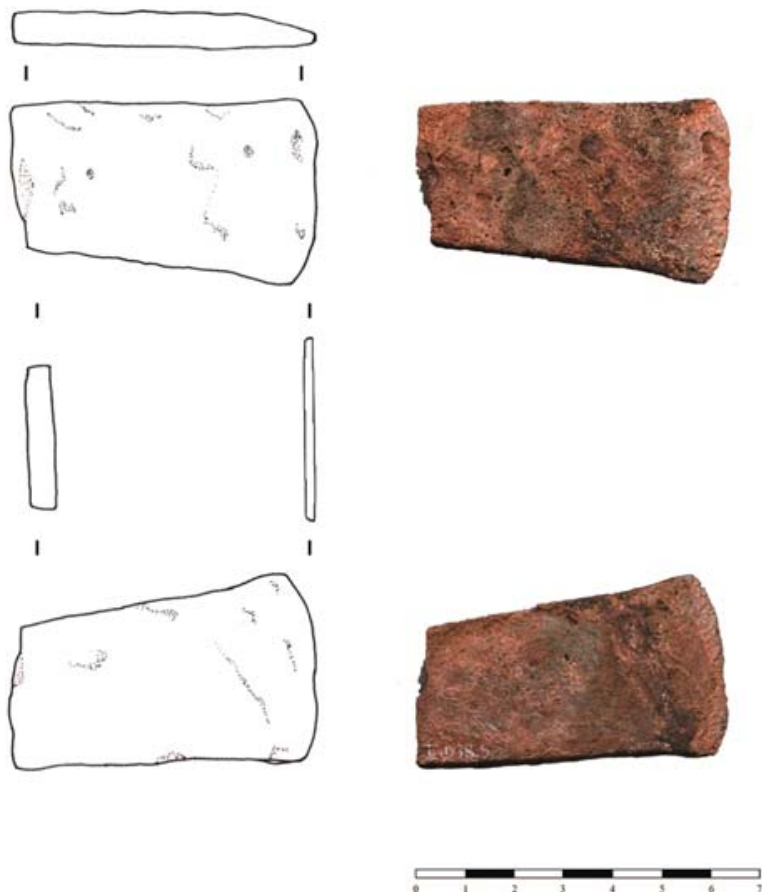

Fig. 1 - Drawing and photograph of axe cat. no. 1 (unpublished). 

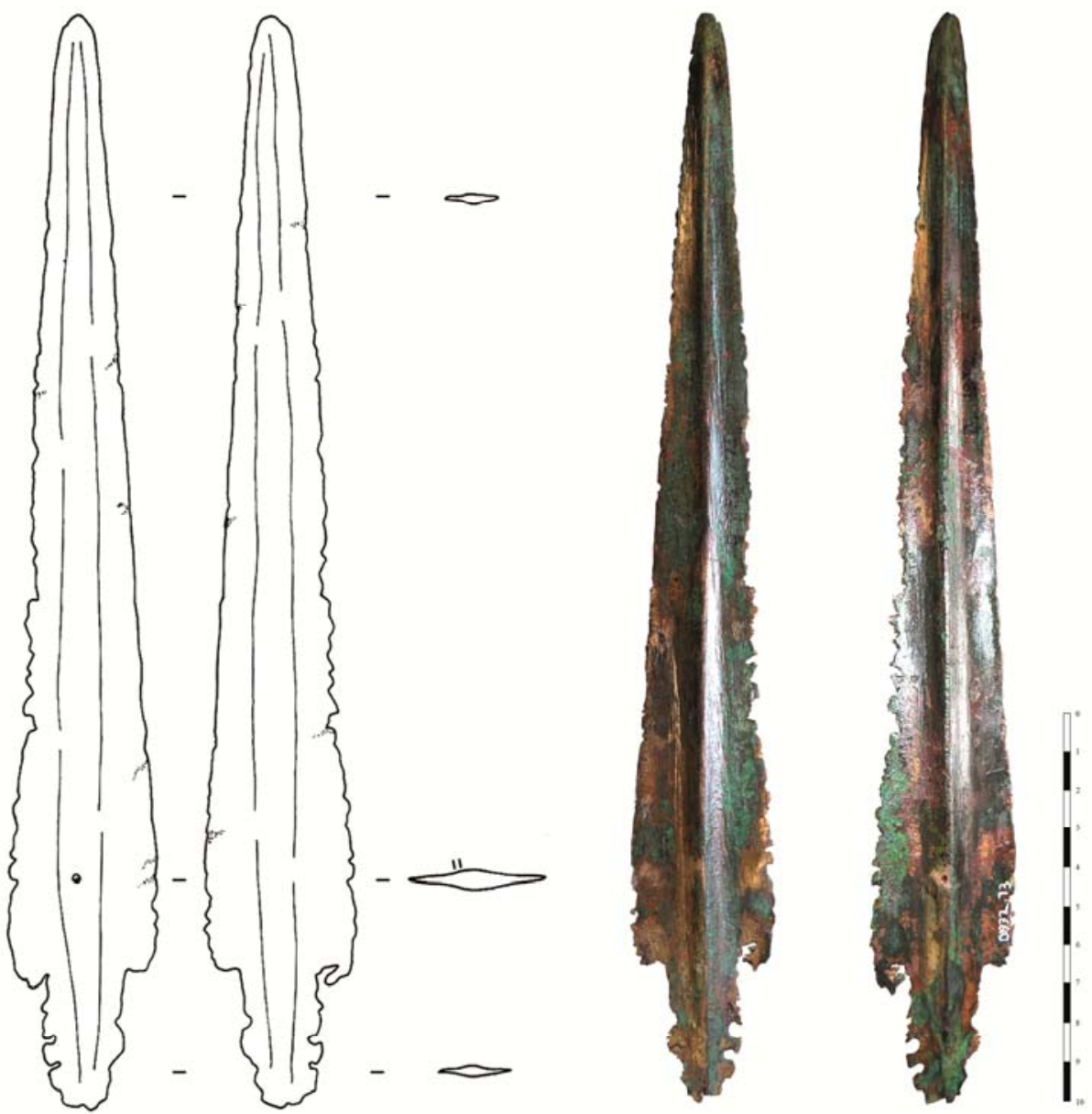

Fig. 2 - Drawing and photograph of dagger cat. no. 2 (Petrie 1932, pl. XII:62). 


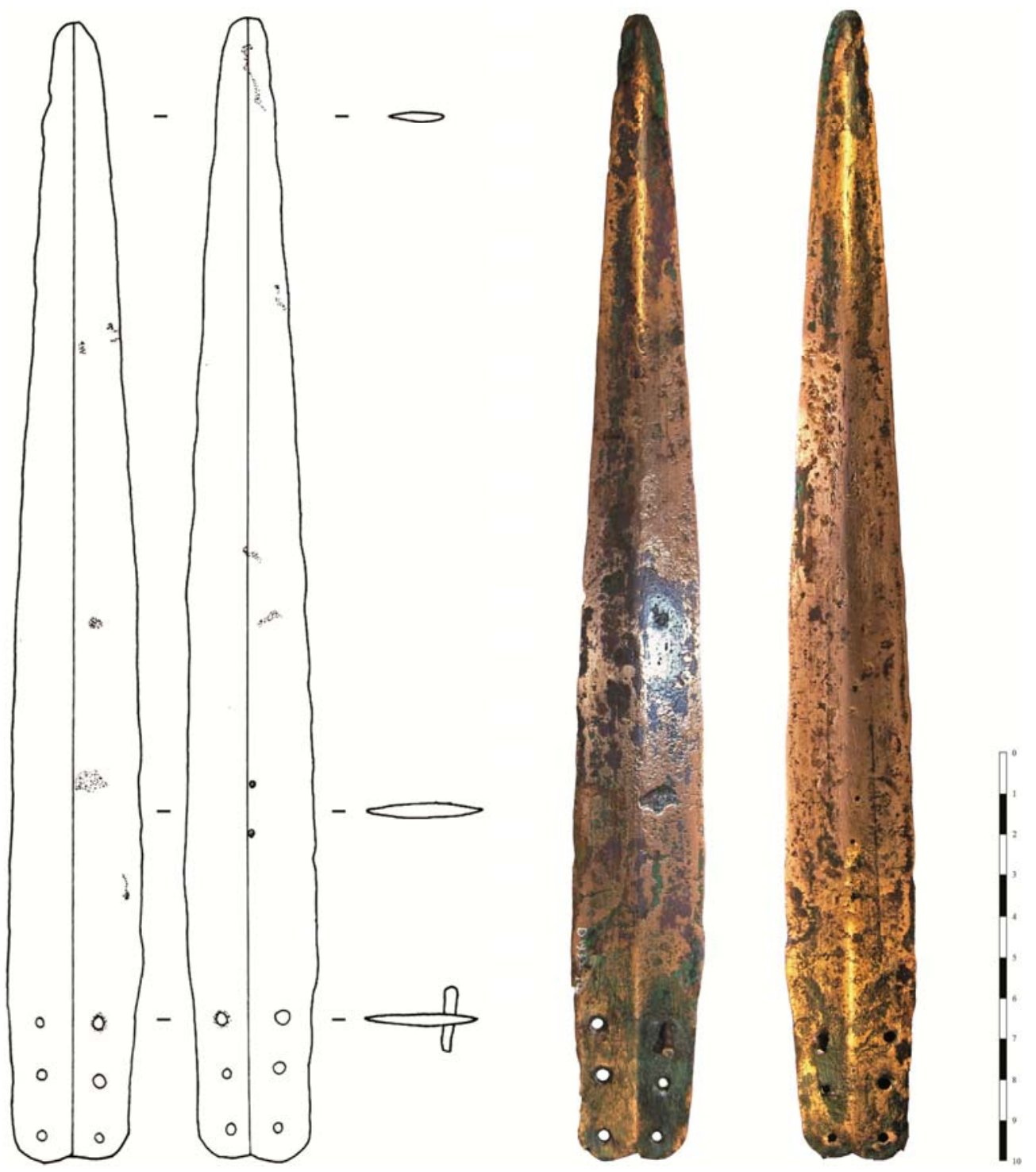

Fig. 3 - Drawing and photograph of dagger cat. no. 3 (Petrie 1932, pl. XI:53). 

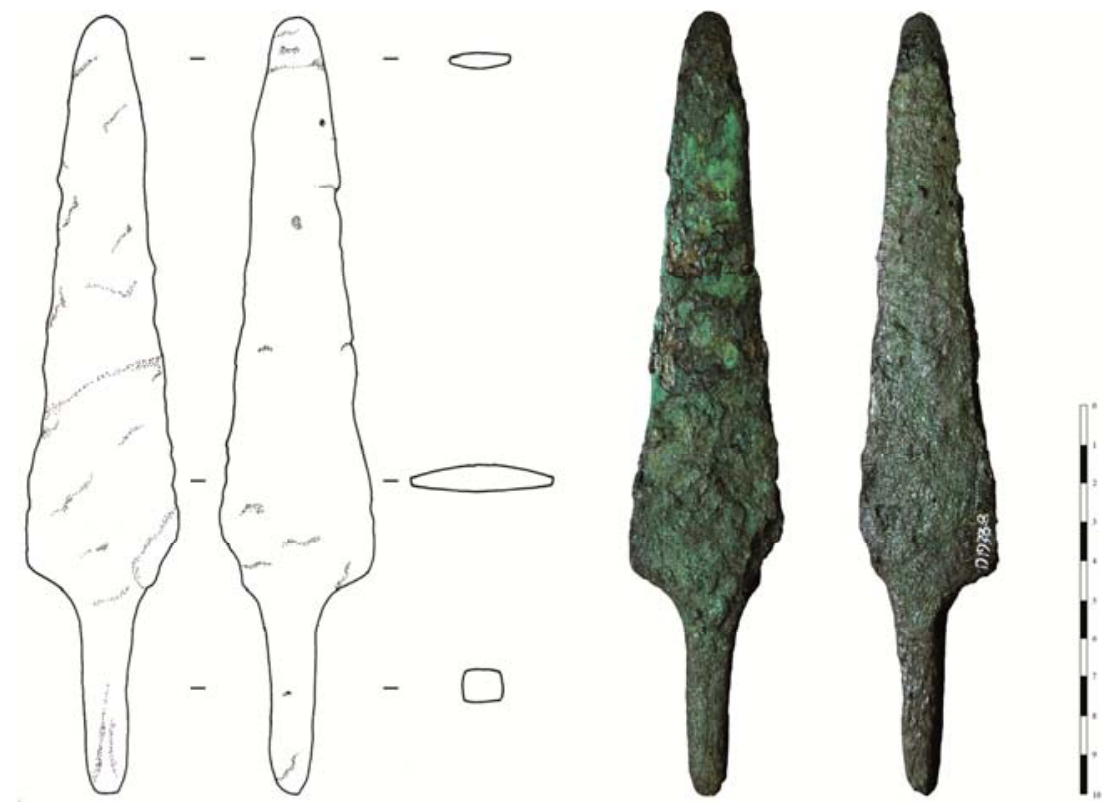

Fig. 4 - Drawing and photograph of dagger cat. no. 4 (Petrie 1933, pl. XVIII:3).
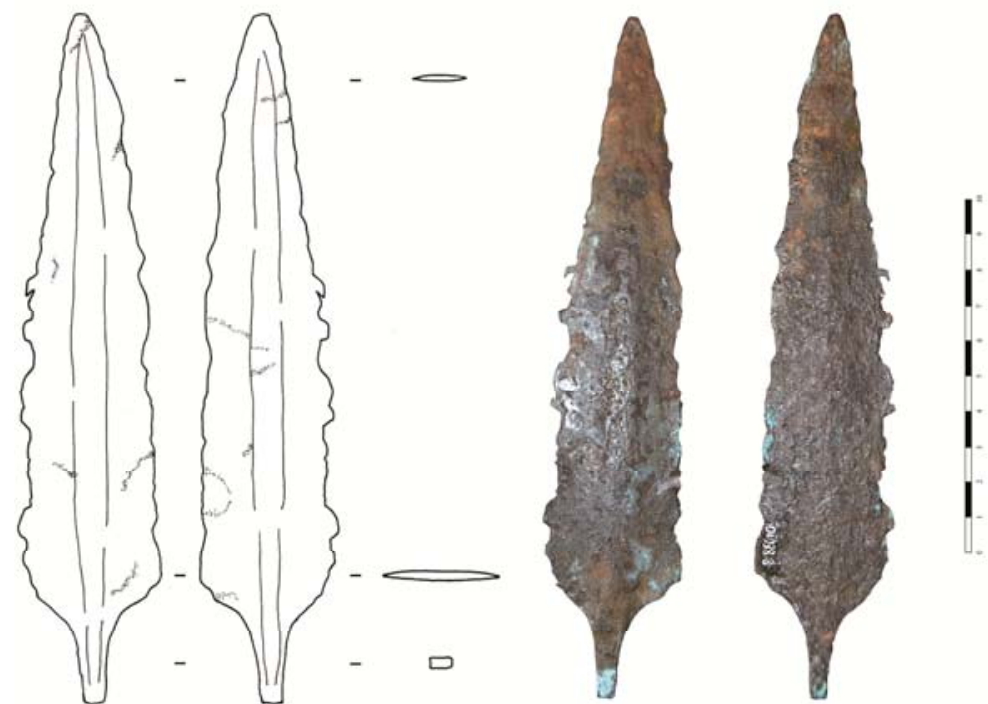

Fig. 5 - Drawing and photograph of dagger cat. no. 5 (Petrie 1934, pl. XXVII:285). 

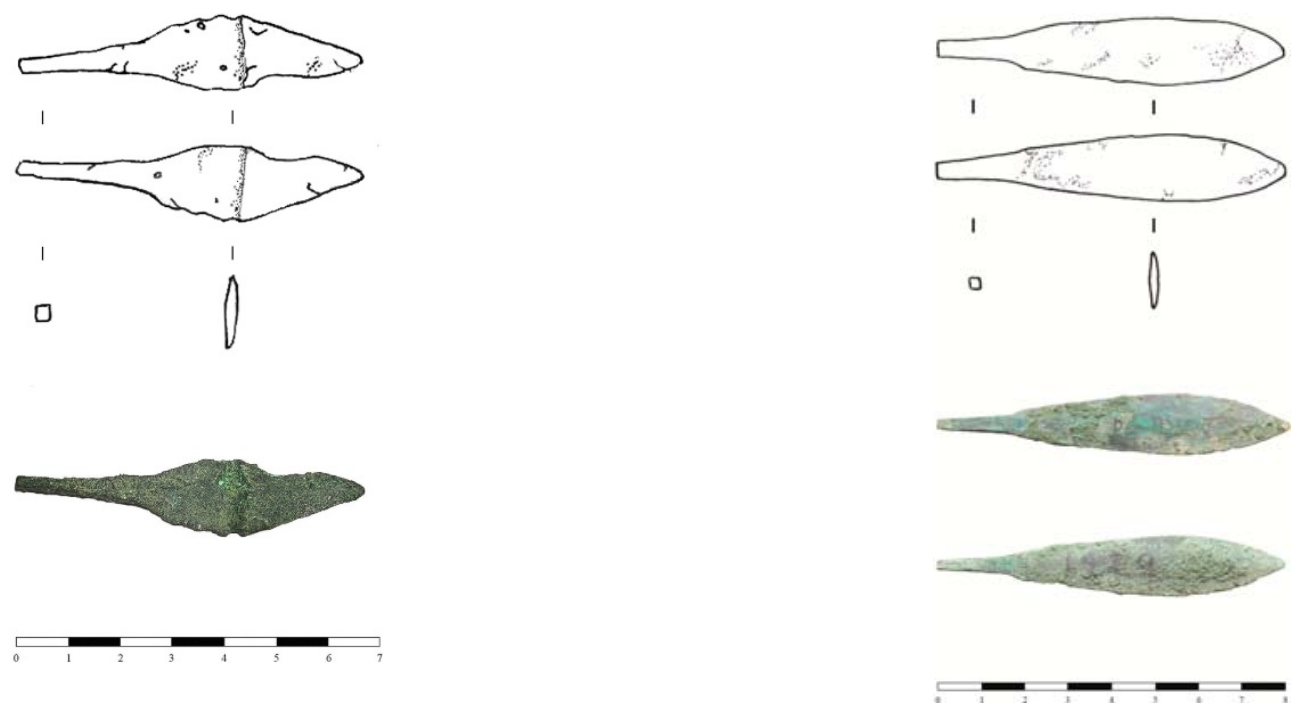

Fig. 6 - Drawing and photograph of arrowhead cat. no. 6 (unpublished).

Fig. 7 - Drawing and photograph of arrowhead cat. no. 7 (unpublished).
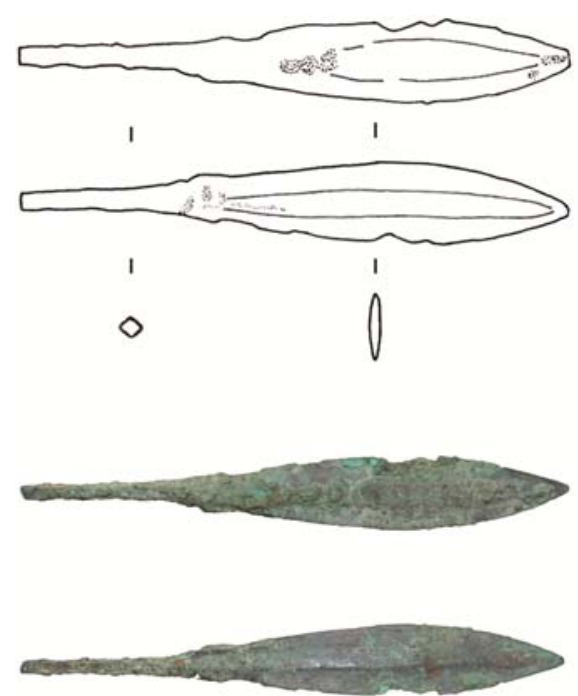

Fig. 8 - Drawing and photograph of arrowhead cat. no. 8 (unpublished). 